\title{
Is More 'Brussels' the Solution? New European Union Member States' Preferences about the European Financial Architecture
}

Citation for published version (APA):

Spendzharova, A. (2012). Is More 'Brussels' the Solution? New European Union Member States' Preferences about the European Financial Architecture. Journal of Common Market Studies, 50(2), 315334. https://doi.org/10.1111/j.1468-5965.2011.02208.x

Document status and date:

Published: 01/01/2012

DOI:

10.1111/j.1468-5965.2011.02208.x

Document Version:

Publisher's PDF, also known as Version of record

Document license:

Taverne

Please check the document version of this publication:

- A submitted manuscript is the version of the article upon submission and before peer-review. There can be important differences between the submitted version and the official published version of record.

People interested in the research are advised to contact the author for the final version of the publication, or visit the DOI to the publisher's website.

- The final author version and the galley proof are versions of the publication after peer review.

- The final published version features the final layout of the paper including the volume, issue and page numbers.

Link to publication

\footnotetext{
General rights rights.

- You may freely distribute the URL identifying the publication in the public portal. please follow below link for the End User Agreement:

www.umlib.nl/taverne-license

Take down policy

If you believe that this document breaches copyright please contact us at:

repository@maastrichtuniversity.nl

providing details and we will investigate your claim.
}

Copyright and moral rights for the publications made accessible in the public portal are retained by the authors and/or other copyright owners and it is a condition of accessing publications that users recognise and abide by the legal requirements associated with these

- Users may download and print one copy of any publication from the public portal for the purpose of private study or research.

- You may not further distribute the material or use it for any profit-making activity or commercial gain

If the publication is distributed under the terms of Article $25 \mathrm{fa}$ of the Dutch Copyright Act, indicated by the "Taverne" license above, 


\title{
Is More 'Brussels' the Solution? New European Union Member States' Preferences about the European Financial Architecture*
}

\author{
ANETA SPENDZHAROVA \\ Maastricht University
}

\begin{abstract}
The changes in the European financial architecture in the aftermath of the 2008 global financial crisis have highlighted the tension between the need for greater centralization of financial regulation at the EU level and the reluctance of some Member States to give up national regulatory autonomy. This article analyses the attitudes of new EU Member States toward the EU financial regulatory reforms. It investigates whether the extent of foreign ownership in the domestic financial sector, Euroscepticism, government support for deregulation and recent experiences of a severe financial crisis have an impact on countries' reservations. According to the results of the analysis, the higher the foreign ownership of a country's financial sector, the more reservations it expresses. The Eurosceptic attitude of the political parties in government matters as well. The more the governing political parties are opposed to EU integration in general, the more reservations one finds in a country's official position on the new EU financial architecture.
\end{abstract}

\section{Introduction}

The new European financial architecture, redesigned in the aftermath of the 2008 global financial crisis, brings about the most extensive and systematic overhaul of financial sector regulation in the European Union. Named after the chairman of the high-level expert group on financial supervision, Jacques de Larosière, the framework will have a substantial and lasting impact on the regulatory systems of the Member States. For example, the centralization of financial supervision entails a transfer of decision-making power from the national supervisory authorities to new European authorities. While this is not a simple zero-sum game in which the national authorities are bound to lose out, transferring some competences is inevitable in order to make the single European financial regulatory regime work. It is still an open question what gains in economies of scale, informationsharing and more effective risk management can offset sovereignty losses.

EU Member States with large financial sectors such as the United Kingdom, France and Germany have scrutinized the regulatory proposals and defended their policy preferences quite vocally (Parker and Masters, 2009; EurActiv, 2010; Quaglia, 2010). By contrast, the literature has not examined systematically the policy preferences of the EU's central and eastern European new Member States. Having joined the Union in 2004 and 2007, those

\footnotetext{
* I would like to thank Rachel Epstein, Paul Stephenson, Dimiter Toshkov, Milada Vachudova, Sophie Vanhoonacker and two anonymous JCMS reviewers for their constructive comments on earlier versions of this article. I am grateful to the participants in the PCE research colloquium at Maastricht University, the University of Mannheim workshop 'PolicyMaking in Hard Times', ECPR Joint Sessions Workshop 18 in 2010 and Workshop 16 in 2011 for their helpful feedback.
} 
states are relative newcomers to EU decision-making. In issues of regulatory governance, they tend to be rule-takers rather than active rule-makers (Goetz, 2004; Vachudova, 2005; Sissenich, 2006). However, the stakes in the current financial regulation overhaul are high, given the large foreign (predominantly EU) ownership of their financial sectors (ÖNB, 1999; Fries, 2005). It is important to understand the attitudes of new EU Member States toward the current financial regulatory reforms because the region is increasingly economically interconnected with the rest of the EU and any regulatory failures in central and eastern Europe will have negative repercussions for the Union at large.

For all EU Member States, the key question in the financial regulatory overhaul was which responsibilities to transfer to the European level and which to keep at the national level. The financial crisis showed that EU supervisory convergence under the Lamfalussy framework was insufficient. At the same time, enhanced co-operation and co-ordination among the national supervisory authorities are essential because the stability of the European financial system depends on 'the weakest link in the chain' (Bini Smaghi, 2009). How can national regulatory authorities be integrated closely in a centralized European framework without a significant loss of national regulatory powers? To tackle this question, we need to understand better Member States' reservations about the new European financial architecture.

This article analyses the official positions of central and eastern European EU Member States on the de Larosière financial regulation policy package. The article begins with an overview of the institutional features and innovative aspects of the de Larosière framework. Then, it considers the politics of regulatory reform and why some Member States are reluctant to transfer power to the EU level. In the following section, five hypotheses about the sources of variation in countries' reservations are tested. The impact of foreign ownership of the financial sector, Euroscepticism, government attitude toward deregulation and recent experiences of a severe financial crisis are then explored. The results support the foreign-ownership hypothesis: the larger the market share of foreign banks, the more reservations countries express about transferring regulatory power to the EU level. Furthermore, the Eurosceptic attitude of the political parties in government matters. The more the governing political parties are opposed to EU integration in general, the more reservations we find in a country's official position on the new EU financial architecture. The final section sums up the main findings of the article.

\section{EU Financial Regulation since 1999: From Lamfalussy to de Larosière}

The 2008 global financial crisis highlighted the weaknesses of the single passport European financial system designed in the 1980s and 1990s and the need to overhaul the EU's financial regulation (Lannoo, 2008; Begg, 2009; Hodson and Quaglia, 2009). Let us consider a few important earlier milestones in EU financial regulation before we discuss the main features of the de Larosière framework. The first overarching policy at the EU level in the realm of financial markets and services was the Financial Services Action Plan (FSAP) for the period 1999-2005. However, due to the slow implementation of the FSAP, in 2000, the Ecofin Council of Ministers appointed a Committee of Wise Men chaired by Alexandre Lamfalussy, which put forward a series of measures to achieve EU-wide convergence in regulating securities markets. Ultimately, it developed the four-level 
regulatory approach shown here in Appendix I. The so-called 'Lamfalussy framework' was adopted in 2002 after lengthy negotiations between the European Commission and the European Parliament. The principles outlined in the Lamfalussy Report for the securities sector were also extended to banking and insurance (Quaglia, 2007). In 2004, the Commission reviewed the Lamfalussy process and engaged in extensive consultations to fine-tune its implementation. The Commission's White Paper on Financial Services, 2005-2010, succeeded the FSAP (Commission, 2005).

Level 3 committees, commonly referred to as ' $3 \mathrm{~L} 3 \mathrm{~s}$ ', are an important feature of the Lamfalussy framework. The three committees - CEBS (banking), CESR (securities) and CEIOPS (insurance) - were set up to foster the exchange of best practices across Member States and sectors and facilitate the convergence of regulatory outcomes (ECB, 2007). However, they could only issue non-binding recommendations. In November 2005, the three committees signed a joint protocol on co-operation to ensure greater coherence and consistency in their actions. The target actions were information-sharing, exchange of experience, reducing duplication of reporting, issuing joint reports and strategies for future development (ECB, 2007). During the 2007 evaluation of the Lamfalussy process, Ecofin suggested that level 3 committees strengthen the national application of their guidelines, standards and recommendations. However, it did not recommend upgrading the non-binding status of their recommendations in order to give them 'more teeth' (ECB, 2007).

In the aftermath of the 2008 global financial crisis, the European Commission launched a new initiative to redesign the European financial architecture, following the recommendations of the de Larosière Report (Commission, 2009a). It envisaged the creation of a European Systemic Risk Board (ESRB) that would be in charge of macro-prudential supervision - monitoring and assessing systemic risk in European financial markets (Commission, 2009b). A second institution - the European System of Financial Supervisors (ESFS) - would complement the ESRB in the area of microprudential supervision. In September 2010, the Ecofin Council of Ministers and the European Parliament gave the final seal of approval for the creation of the ESRB and the ESFS (Tait, 2010). The ESFS includes three new European Supervisory Authorities in banking, securities and insurance, shown here in Appendix II (Commission, 2009c).

The first new institution - the European Systemic Risk Board - has been fairly uncontroversial. It will monitor risks to financial stability in the EU-27 and its membership will comprise the 27 national central bank governors of the EU Member States, the two top European Central Bank officials, as well as representatives of the Commission and the three newly created European Supervisory Authorities. The ECB will provide the ESRB's secretariat; the Board's chair and vice-chair will be elected (Commission, 2009b; Tait, 2009). The ESRB can request and pool data from the national supervision authorities and central banks of the Member States. At the same time, its recommendations will be confidential. With respect to sectoral representation, central bankers are the dominant group in this body. Of course, once the ESRB becomes fully operational, it will have to determine what is considered systemic risk, what range of economic parameters will be assessed and monitored, and what actions will be taken in response to perceived threats to financial stability. The ECB is currently involved in developing working papers and the framework for this assessment (EurActiv, 2010). 
The second proposed institution - the European System of Financial Supervisors - has caused significant debate, especially with regards to the powers of the new European Supervisory Authorities - the European Banking Authority (EBA), the European Securities and Market Authority (ESMA) and the European Insurance and Occupational Pensions Authority (EIOPA). The de Larosière regulatory framework generally builds upon the institutional features of the Lamfalussy one. However, level 3 committees (3LSs) received a strong institutional upgrade, becoming European Supervisory Authorities. Among the core functions of the three authorities are developing and enforcing a common supervision rule book in their respective sector and issuing binding decisions to ensure greater regulatory coherence. These enhanced powers of the European Supervisory Authorities have become the bone of contention among the Member States.

\section{Why Reluctance to Transfer Regulatory Power to the EU Level?}

Member States disagreed about how to strike a balance between supranational regulation and national regulatory autonomy during the negotiations of the new EU financial architecture. Scholars and policy-makers have recognized the need for greater centralization of financial regulation at the EU level, but they have also emphasized the indispensable role of strong national supervisory authorities (Lannoo, 2008; Schoenmaker and Oosterloo, 2008; FSA, 2009). Thus reconciling the two objectives was a major part of the policy negotiations. This section explores a number of common concerns among Member States which were more reluctant to transfer regulatory powers to the EU level. I draw on a set of semi-structured interviews with members of the Brussels Permanent Representations of both old and new Member States who participated in the negotiations of the new European financial architecture in 2009.

Among old Member States, France advocated greater centralization of regulatory power at the EU level, supported often by Italy, Portugal and the Netherlands. By contrast, the United Kingdom expressed the most vocal concerns about extensive transfer of competences from the national to the EU level. Britain's reservations were often supported by Spain and the Czech Republic (Personal Interview 1, 2010; Personal Interview 2, 2010).

Paul Myners, United Kingdom Financial Services Secretary from October 2008 until May 2010, explained Britain's main concerns about the new European financial architecture in a House of Lords hearing. He pointed out that accountability was a major problem. At the end of the day, national finance ministries and central banks would bear the responsibility for bank bail-outs and would be held accountable for their actions - not the European Supervisory Authorities. Myners stressed that 'in the absence of such accountability, it could make a crisis much harder to manage or resolve' (House of Lords European Union Committee, 2009, pp. 12-13). He added that centralized European supervisory bodies would also lead to a loss of regulatory diversity because they would deny national supervisors the ability to fine-tune regulations to their national context, experiment and learn from each other.

The United Kingdom's main reservations about the new EU financial regulatory framework were echoed by a number of new Member States. As one negotiator from a new Member State Permanent Representation summed up: 'Power must be linked to responsibility. Giving the European Authorities a lot of regulatory power, while leaving all the 
responsibility at the national level creates more hazard in the end' (Personal Interview 4, 2011). New Member States acknowledged that more regulatory co-operation was necessary and desirable and were not apprehensive about transferring power to the supranational level per se. They did worry, however, about the fiscal and accountability consequences of transferring regulatory power to the EU. Czech central bankers were particularly prominent in voicing their concerns. In a recent interview, the vice-governor of the Czech Central Bank, Mojmír Hampl (2010) described the new European financial regulatory framework as follows:

This is a classic bureaucratic response: faced with a problem, create a new institution. What a mistake. If we merely add new institutions to EU countries' already Byzantine arrangements, we will fail to address the effectiveness, flexibility and smoothness of information transfer through the EU-level supervisory system [. . .] we need to start with national supervisors first and then if necessary go higher to the European level, not the other way round.

Furthermore, the early policy proposals lacked a clear vision how to put the regulatory framework in practice. For example, one interviewee pointed out that it was not specified how claims against decisions by the European Supervisory Authorities would be filed and processed (Personal Interview 4, 2011). To placate such concerns, in December 2009, the Ecofin Council of Ministers reached an important agreement about the so-called 'triplelock' safeguard. This mechanism ensures that Member States have multiple appeal options at their disposal regarding decisions taken by the three new European authorities. As a first option, a Member State can appeal a decision in the Ecofin Council. A simple majority of at least 14 Member States can then overturn that decision. The European Court of Justice is the next level of appeal. As a last resort, a country can also appeal a decision in the European Council if the first two measures fail (EurActiv, 2009a, b).

Home-host supervision arrangements in the new regulatory framework were a particular concern for central and eastern European Member States. New Member States that are predominantly hosting foreign financial institutions were worried that the new rules would leave them in a weak position to oversee the domestic market (Personal Interview 3, 2010). National regulators, especially in the banking sector, raised an alarm that giving the European Supervisory Authorities the power to issue binding decisions on individual cases could result in new Member States' footing the bill for bail-outs of foreign branches and subsidiaries operating in their jurisdiction. Furthermore, the initial policy proposals seemed to limit the range of national discretions available to Member State regulators to impose more stringent capital requirements on foreign-owned branches and subsidiaries. Thus the balance sheet looked rather troubling to some national financial regulators: the state would take on a fiscal burden if a bail-out was necessary, but it would give up regulatory power over the domestic market. Let us now examine more systematically the reasoning behind new Member States' reservations toward the new European financial architecture.

\section{Comparing New Member States' Positions on the EU Financial Regulation Reforms}

This section clarifies the dependent variable in the hypothesis-testing part of the article: number of reservations about transferring regulatory powers. The reservations score, 
shown in the last column of Appendix III, is an additive index composed of the total number of reservations expressed by Member States in their official position on the de Larosière policy proposals. While this part of the article engages in a qualitative analysis of new Member States' official positions, we still need to establish clear benchmarks for a systematic comparison. As discussed earlier, the central tension is between, on the one hand, the need to centralize regulatory power at the EU level in order to benefit from economies of scale and, on the other hand, the distribution of responsibilities between the national and the EU levels (Begg, 2009; Masciandro et al., 2009). Thus, I will examine the opinions regarding the following themes: national versus supranational competences; national discretions; and dispute settlement mechanisms. Appendix III summarizes the results of the analysis.

First, in the multi-level governance structure of EU financial supervision, the envisioned European Supervisory Authorities will need 'teeth' in order to be taken seriously. Under the new legal framework, the European Supervisory Authorities can issue legally binding decisions that could, in theory, trump Member States' regulatory preferences (Commission, 2009c). Thus we need to investigate Member States' views on the desirable division of national and supranational competences in financial regulation.

Second, the European Supervisory Authorities will rely on Member State regulators for a steady supply of information, day-to-day supervision, and taking the fiscal responsibility for EU regulatory decisions and possible bail-outs. For example, the so-called 'burden-sharing' provisions may entail that Member States' taxpayers will be forced to bail out the domestic parts of insolvent cross-border institutions, which are supervised predominantly by foreign and the European authorities. A very fine balance must be established between decision-making powers and the fiscal responsibilities for those decisions. With this in mind, we may expect Member States to request keeping in place the system of national discretions in sensitive domestic circumstances.

Third, conflicts between national supervisory institutions and the European Supervisory Authorities are likely to emerge. The rationale becomes clearer when we look at the existing accountability arrangements. At the EU level, the European Supervisory Authorities can be called to account for their decisions and actions before the European Parliament. Similarly, national supervisory bodies are held accountable by their national parliament and government. Yet, according to the new European financial architecture, a national supervisory body will be responsible for implementing decisions taken at the European level. What will happen if a Member State government disagrees with the binding recommendations of the European Supervisory Authorities and decides to pressure the national supervisory authority to intervene in matters that are practically beyond its competences? We could expect Member States to be rather concerned about establishing a fair and credible system of dispute settlement in case of conflict between national supervisory bodies and their European counterparts. I will now elaborate on each theme in turn, using examples from the official positions.

\section{National versus Supranational Competences}

A first set of arguments explaining new Member States' reservations about transferring regulatory responsibilities to the EU level refers to the preservation of important supervisory competences at the national level. One of the countries expressing most 
reservations, the Czech Republic, rejects the proposed European System of Financial Supervisors altogether because 'it is unacceptable to weaken national supervisory authorities' powers, particularly in emergency situations when they are directly responsible for maintaining financial stability' (Czech Republic, 2009, p. 4). Another country with many reservations, Estonia, is concerned about the ambiguity in the Commission's Communication regarding the division of responsibilities between the national supervisory bodies and the envisaged European ones. The position stresses that 'existing national supervisors should continue to carry out day-to-day supervision over the existing supervised entities' (Estonia, 2009, p. 3). The Slovak Ministry of Finance also calls for a clear division of labour between the ESRB and the national supervisory bodies: '[T]he ESRB should not interfere with the competences of the national supervisors, as its main task would be to assess the systemic risks at macro-prudential level' (Slovakia, 2009, p. 1).

According to the legislative proposals, the new European Supervisory Authorities will be able to decide on capital add-ons for individual financial institutions. The Polish Financial Supervision Authority considers this 'a significant shift of powers' that would deprive national supervisors of a crucial supervisory competence (Poland, 2009, p. 2). Because capital requirements are an important lever to control the level of risk that an institution can take in the local market, the Polish FSA wants to keep this competence in the hands of national authorities.

The supervision of cross-border financial institutions is another very sensitive issue for the EU's new Member States. The Slovak Ministry of Finance is wary of shifting powers away from national supervisors to the so-called 'home' regulators of cross-border entities (Slovakia, 2009, p. 2). The Romanian and Polish positions echo this concern: the 'host' supervisor should have sufficient regulatory power to influence the national market in case a subsidiary is in worse condition than its parent company or the cross-border group as a whole (Romania, 2009; Poland, 2009).

The Hungarian position on the new EU financial regulatory framework pays special attention to the issue of supervisory colleges for cross-border financial institutions. The Hungarian Ministry of Finance supports supervisory colleges in the short term in order to facilitate the day-to-day supervision of cross-border financial conglomerates, but it suggests that this system should be changed in the long term in order to establish a more institutionalized framework (Hungary, 2009a, p. 2). The Hungarian National Bank warns that 'the development of supervisory practices at the college level can lead to fragmentation' (Hungary, 2009b, p. 2). According to the central bank, this is due to the different levels of risk tolerance and risk perception among different colleges of supervisors, even within the same Member State, which is a 'threat to comparability and equal standards' (Hungary, 2009b, p. 2).

\section{National Discretions}

While most central and eastern European Member States recognize the need to eliminate some national discretions in order to achieve and sustain regulatory harmonization in the EU, most positions call for preserving the system of national discretions. The Polish Financial Supervision Authority demands a careful assessment of which national options and discretions are crucial for the functioning of national supervisors and need to remain in place (Poland, 2009, p. 1). Estonia is willing to give up some national discretions 'in the 
name of larger harmonization and far-reaching EU Single Market', but it also advocates the renewal of national discretions and flexibility mechanisms, especially in the realm of crisis management (Estonia, 2009, p. 5). The Hungarian Central Bank generally supports regulatory harmonization at the EU level, but it advocates national discretions and opposes the creation of 'a single uniform rule book for the community as a whole' (Hungary, 2009b, p. 1).

Rather critical toward the proposed EU financial regulation architecture, the Czech position departs from the tone of other new Member States and explicitly calls for the elimination of all national discretions. At the same time, it rejects the transfer of power to the EU level altogether: 'We cannot accept the model of European financial market regulation and supervision proposed in the EFS document' (Czech Republic, 2009, p. 2). Thus the call to eliminate national discretions is in the context of relying exclusively on national regulatory solutions to ensure the stability of the financial sector.

\section{Dispute Settlement}

The last set of arguments explaining new Member States' reservations about transferring supervisory responsibilities to the EU level refers to the proposed dispute resolution system. The bone of contention here is the binding power of decisions issued by the new EU supervision authorities. Needless to say, without binding power, the European regulators will have no 'teeth'. However, can Member States trust their judgement unconditionally? The dispute settlement aspect of the European financial sector regulatory architecture is problematic for most new Member States. Countries expressing many reservations toward transferring powers to the EU level such as the Czech Republic, Estonia and Poland are vocal against some of the proposed mechanisms. For example, Estonia is against the proposal for ECB binding mediation to resolve conflicts among national and European financial sector supervisors. According to the Estonian position, the mandate of the ECB should be limited to monetary policy and ensuring financial stability (Estonia, 2009, p. 3).

On the micro-prudential level, the Slovak position is explicitly against authorizing the European Supervisory Authorities to issue legally binding technical decisions applicable to individual institutions supervised by the national authorities. Slovakia also opposes legally binding EU mediation between national supervisors in case of conflict (Slovakia, 2009, p. 2). Furthermore, the Hungarian Ministry of Finance expresses concerns that the proposed system of peer review recommendations in the ESFS will result in de facto binding advice that constrains the national supervisory authorities (Hungary, 2009a, p. 2).

Latvia's position highlights the difficulty of reconciling binding EU dispute resolution with the primary mandate of national supervisors to oversee the stability of the national financial market (Latvia, 2009, p. 3). The Romanian position adds a fiscal concern: binding dispute resolution competences of the European authorities can trump decisions taken by the national regulators. However, in the end, national regulators bear the fiscal responsibility for implementing the regulatory measures (Romania, 2009, p. 2). Consistent with its general position on the new EU financial architecture, the Czech Central Bank maintains that the transfer of decision-making powers to the European level while fiscal liabilities remain with the national supervisors is unacceptable. It is particularly difficult for national supervisory bodies to align their actions with both national and European 
priorities: 'A national supervisory authority is accountable to its national parliament, and in some cases partially to its national government, and cannot simultaneously be accountable to the European authorities' (Czech Republic, 2009, p. 5).

\section{Determinants of New EU Member States' Reservations about the de Larosière Framework}

Now that we understand better new Member States' reservations about the European financial architecture, I will investigate what the most important determinants of variation in those reservations are, taking into account the region's political economy. Large foreign ownership is a first striking feature of new Member States' financial sectors. In the early and mid-1990s almost all central and eastern European countries liberalized their financial sectors, but scholars have observed significant variation in states' willingness to accept high levels of foreign ownership (Bonin and Wachtel, 1999; Epstein, 2008a). Currently, the most developed part of financial services in the region - banking - is dominated by large European banks such as UniCredit, Raiffeisen and Société Générale (Berglöf and Bolton, 2002; Fries, 2005). While the sweeping privatization of assets across the economy was generally accepted as a necessity in the 1990s (Vachudova, 2005), many policymakers and practitioners in the region are now rethinking the scope of foreign ownership and role of government regulation (Lindstrom and Piroska, 2007; Estrin, 2009; Morow, 2009).

According to the first hypothesis tested here, the stronger foreign banks are in the domestic market, the more reservations a Member State will express about transferring regulatory powers to the EU level. This proposition is broadly grounded in the insights of the varieties of capitalism literature that the structure of the national economy shapes policy-makers' regulatory choices (Hall and Soskice, 2004). Furthermore, we know that international institutions' push for more financial sector liberalization was met with resistance in central and eastern European countries where nationalist striving and desire for autonomy were high (Epstein, 2008b; Vachudova, 2008). The causal mechanism behind the first hypothesis is that the 'host' domestic regulators already have less regulatory power than the 'home' supervisors of the foreign financial institutions. A further transfer of regulatory powers to the EU level can undermine completely the ability of 'host' regulators to influence the behaviour of financial institutions active in their national market.

H1: The larger the market share of foreign banks, the more reservations countries express about transferring regulatory powers to the EU level.

At the same time, economic interests and the structure of the domestic market may not be the main factors shaping policy-makers' stance on transferring regulatory powers to the EU level. According to the two-level games literature in international relations (Gourevitch, 1978; Putnam, 1988), a mobilized domestic audience can constrain the government's position in international negotiations. In this case, a more Eurosceptic public may compel the government to defend more staunchly the decision-making powers of national financial regulators vis-à-vis their European counterparts. ${ }^{1}$ This argument resonates with

\footnotetext{
${ }^{1}$ I thank Lucia Quaglia for pointing out the relevance of Euroscepticism.
} 
research on new Member States' uneven progress toward qualifying for eurozone membership due to the high domestic costs of reining in government spending and observing the strict conditions of the Stability and Growth Pact (Johnson, 2008).

H2: The more Euroscepticism is present in the domestic political system, the more reservations countries express about transferring regulatory powers to the EU level.

Furthermore, the partisan preferences of the governing parties may also affect the country's position. Here, I expect political parties in favour of deregulation to be more open to European solutions because they bolster the single market. I will, therefore, investigate whether governing political parties in favour of deregulation express fewer reservations toward the new European financial architecture.

H3: Governments in favour of deregulation express fewer reservations about transferring regulatory powers to the EU level.

In the aftermath of the global financial crisis, emerging economies such as those in central and eastern Europe faced growing current account deficits and external debts (GriffithJones and Ocampo, 2009). Exploring eight centuries of financial crises, Reinhart and Rogoff (2009) have found that global crises often begin in the most advanced economies, but their effects are quickly passed on to weaker economies such as those in central and eastern Europe through commodity prices, capital flows, interest rates and shocks to investor confidence.

The economic vulnerability of the region may prompt new EU Member States to be more open to supranational solutions. I chose the two most recent financial crises - that of 2008 and the Asian financial crisis of the mid-1990s - to check whether we find evidence for 'policy learning' from crisis and failure (May, 1992; Rose, 1993; Stone, 1999). I expect Member States that were severely affected by the two recent crises to see EU regulation in a more positive light, as a way to pre-empt vulnerabilities in the domestic economy. The causal mechanism behind $H 4$ and $H 5$ below is that severe financial crises induce risk-averse behaviour and make governments more aware of transnational contagion effects.

H4: Countries that experienced a severe crisis in the current period express fewer reservations about transferring regulatory powers to the EU level.

H5: Countries that experienced a severe crisis in the mid-1990s express fewer reservations about transferring regulatory powers to the EU level.

\section{Operationalization and Analysis}

Let us now consider the operationalization of the dependent and independent variables in the analysis and the results of the empirical investigation. I operationalize the dependent variable - reservations about transferring regulatory power to the EU level - using the official Member State positions on the de Larosière policy proposals available at the stakeholder consultation website of DG Internal Market. ${ }^{2}$ The official positions explain the governments' reasoning and any misgivings about the de Larosière policy proposals.

\footnotetext{
${ }^{2}$ A range of national and private actors' official positions are available on the stakeholder consultation website of DG Internal Market: «http://circa.europa.eu/Public/irc/markt/markt_consultations/library».
} 
The article does not analyse Lithuania's preferences as no official position was publicly available. For the hypothesis testing part of this article, the number of reservations in each position paper are counted and summed up in order to derive a composite 'reservations score' shown in the last column of Appendix III. ${ }^{3}$ To ensure transparency of the coding procedure, the reservations themselves are also reported in Appendix III. The higher the score on the reservations index, the more critical a country's position is toward transferring financial sector regulatory powers to the EU level.

I consider the official country positions available on the EU stakeholder consultation website to be representative of the government's position. In each country, the positions were prepared by a national administrative actor such as the finance ministry, central bank or a national financial supervision agency. As the government has the ultimate power to release or withhold a position, in my view, it is reasonable to assume that the publicly available document reflects the government's preferences.

The first independent variable tested in the article is the strength of foreign banks in the domestic market of the central and eastern European EU Member States, measured as the market share of foreign banks in the total amount of domestic assets. Why choose the market share of foreign banks as the relevant indicator? The banking sector in central and eastern Europe is stronger than the securities and insurance ones and has the most assets under management (EBRD, 2010). Thus, the indicator gauges well the relative strength of foreign businesses in the domestic financial markets of new EU Member States.

I operationalize the second independent variable - Euroscepticism - using a public opinion measure and a political party measure. Euroscepticism in the general public is widely measured using standard Eurobarometer survey questions such as 'Do you think that for your country membership in the EU is a good thing, a bad thing, neither a good nor a bad thing' (see, for example, Steenbergen et al., 2007; De Vries and Edwards, 2009). For the purposes of this article, the question 'For each of the following areas [QA36a.10 = Economy], do you think that decisions should be made by the (Nationality) Government, or made jointly within the European Union?' is very appropriate (Commission, 2008). The scores reported in Table 1 are the percentages of respondents saying that in the economic policy area, decisions should be made exclusively by national governments. Thus, a higher score indicates a more Eurosceptic attitude.

In addition, scholars have analysed Euroscepticism in political parties (Taggart and Szczerbiak, 2002; Hooghe et al., 2010; De Vries, 2010). Thus I also investigate whether the level of Euroscepticism in the governing political parties matters. The number reported in Table 1 is the average Euroscepticism score for the governing parties taken from the 2006 Chapel Hill Expert Survey (Hooghe et al., 2010). A lower score means a more Eurosceptic attitude, and the range is $1-7$. I operationalize the deregulation variable using again the 2006 Chapel Hill Expert Survey. The number reported in Table 1 is the average deregulation score for the governing parties. A higher score means that the government is more supportive of deregulation, and the range is $0-10$.

According to $\mathrm{H} 4$ and $H 5$, experiencing a severe crisis makes national regulators more willing to transfer regulatory powers to the EU level. The two most significant recent

\footnotetext{
${ }^{3}$ To make the coding procedure as transparent as possible, one of the sections in this article presents an in-depth exploration of the official positions and further clarifies the dependent variable in the hypothesis-testing part of the article: number of reservations toward transferring regulatory powers to the EU level.
} 


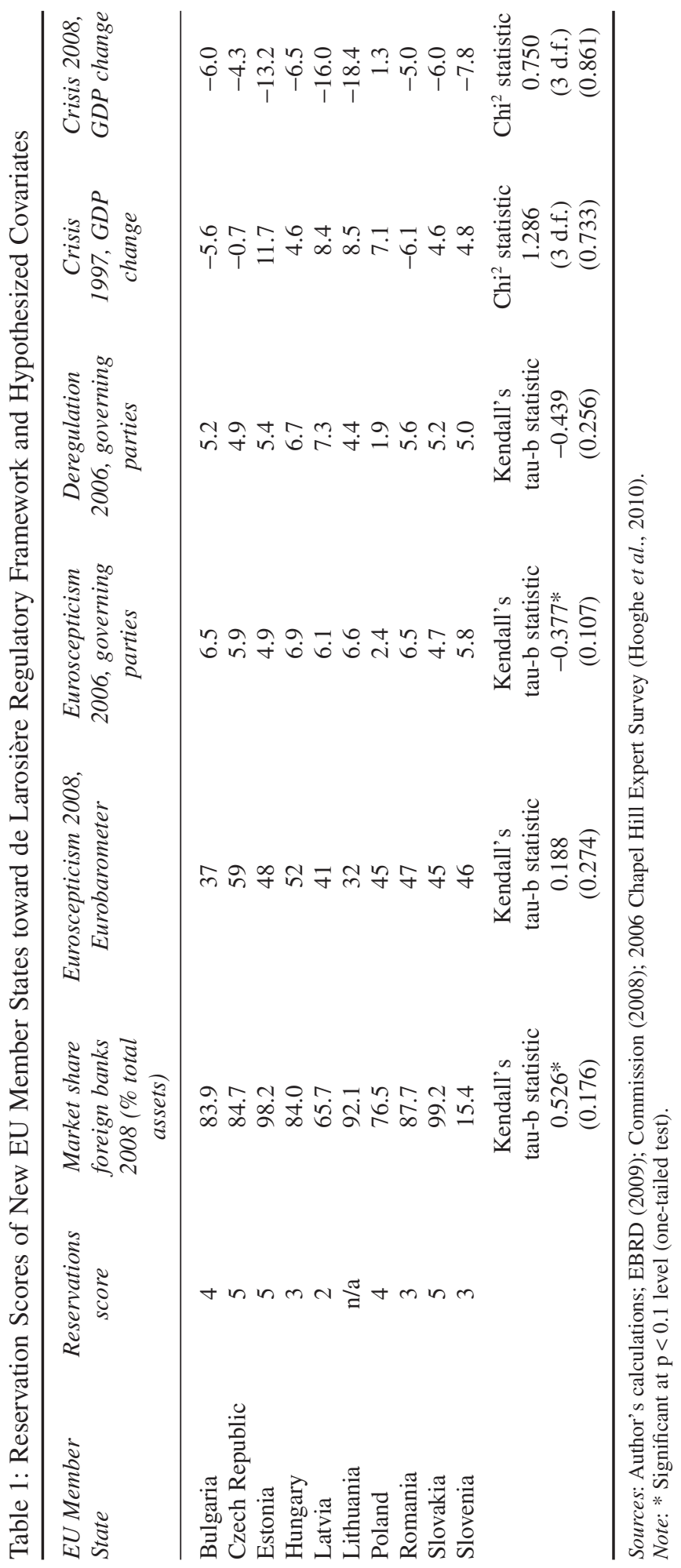


crises relevant for this article are the Asian financial crisis ${ }^{4}$ that affected most emerging economies in the mid-1990s and the global financial crisis of 2008. In both crises, I measure the yearly drop in GDP and take a 6 per cent drop to indicate a severe crisis. The threshold was established based on a Bank for International Settlements analysis indicating that the median depth of economic contraction in the 2008 crisis was 6 per cent (Cecchetti et al., 2009). My reasoning is that a severe economic contraction, larger than this threshold, is likely to elicit a stronger policy response. I expect Member States that were most severely affected by the two recent crises to see EU regulation more positively, as a way to pre-empt transnational contagion effects. Table 1 summarizes the values of the dependent and independent variables.

H1: The larger the market share of foreign banks, the more reservations countries express about transferring regulatory powers to the EU level.

H2: The more Euroscepticism is present in the domestic political system, the more reservations countries express about transferring regulatory powers to the EU level.

H3: Governments in favour of deregulation express fewer reservations about transferring regulatory powers to the EU level.

H4: Countries that experienced a severe crisis in the current period express fewer reservations about transferring regulatory powers to the EU level.

H5: Countries that experienced a severe crisis in the mid-1990s express fewer reservations about transferring regulatory powers to the EU level.

The small number of observations over a one-year period precludes any sophisticated statistical modelling. Instead, I opt for testing the hypotheses separately using bivariate correlations between the variables in the relevant hypothesis. $H 1, H 2$ and $H 3$ are tested using Kendall's tau-b statistic, as the variables are at least ordinal. The statistically significant positive value of the test statistic lends empirical support to $H 1$ : the larger the market share of foreign banks, the more reservations countries express about transferring regulatory powers to the EU level. While the public opinion Euroscepticism variable is not statistically significant, the political parties variable is. The negative statistically significant value of Kendall's tau-b statistic shows that the more opposed the governing parties are to European integration in general, the more reservations the country expresses in its official position. Thus the political parties version of $H 2$ is also supported.

By contrast, the empirical analysis disconfirms $H 3, H 4$ and $H 5$. There is no evidence in the sample that the governing parties' attitude toward deregulation is related to the expressed number of reservations. The effect of crisis was tested as a dummy variable, where a GDP drop of 6 per cent or more was coded as 1 . In both instances of crisis 1997 and 2008 - the $\mathrm{Chi}^{2}$ statistic is not significant. This indicates that there is no relationship between experiencing a severe crisis and the number of reservations expressed about transferring regulatory powers to the EU level. My findings are in line with David Mayes' (2009, p. 1013) conclusion that Nordic countries which had

\footnotetext{
${ }^{4}$ The EBRD data reported in the table were double-checked with World Bank data. There were no discrepancies. I also checked whether any countries in the sample experienced the Asian financial crisis before the most severely affected states, Bulgaria and Romania, but that was not the case. Thus the 1997 GDP growth indicator captures well the overall experience of the Asian financial crisis in the region.
} 
experienced severe financial crises were not more aware of the risks and better prepared to tackle the 2008 global financial turmoil. Experience of crisis alone does not provide sufficient impetus for policy adjustment.

\section{Conclusions}

This article analysed the official positions of central and eastern European EU Member States on the de Larosière financial sector regulatory reform proposals. I tested five hypotheses about the sources of variation in countries' reservations toward transferring regulatory power to the EU level. I also examined in depth the content of new EU Member States' positions, focusing on three aspects: national versus supranational competences, national discretions and dispute settlement. The empirical test confirmed $H 1$ and $H 2$. The larger the market share of foreign banks, the more reservations countries express about transferring regulatory powers to the EU level. In addition, the more the governing political parties are opposed to EU integration in general, the more reservations we find in a country's official position on the new EU financial architecture. However, $H 3, H 4$ and $H 5$ regarding the government's attitude toward deregulation and severe crises were rejected.

The results of the empirical analysis suggest that in policy areas such as financial regulation, which are insulated from public scrutiny and are not frequently discussed in the media, decision-makers are not driven by the general Eurosceptic sentiment of the public. At the same time, I do find evidence that the Eurosceptic attitude of the political parties in government matters. The more the governing political parties are opposed to EU integration in general, the more reservations we find in a country's official position. Furthermore, issue-specific dynamics are quite important when policy-makers decide whether to embrace initiatives for further integration or proceed more cautiously. In the case of central and eastern European Member States, the narrow scope of national regulatory power in the predominantly foreign-owned financial sectors turns out to be a crucial concern. According to my empirical investigation, this is one of the main factors shaping new Member States' preferences about the recent EU financial regulatory reforms.

Correspondence:

Aneta Spendzharova

Political Science Department

Maastricht University

PO Box 616

6200 MD Maastricht

The Netherlands

email a.spendzharova@maastrichtuniversity.nl 
Appendix I: Lamfalussy Regulatory Framework
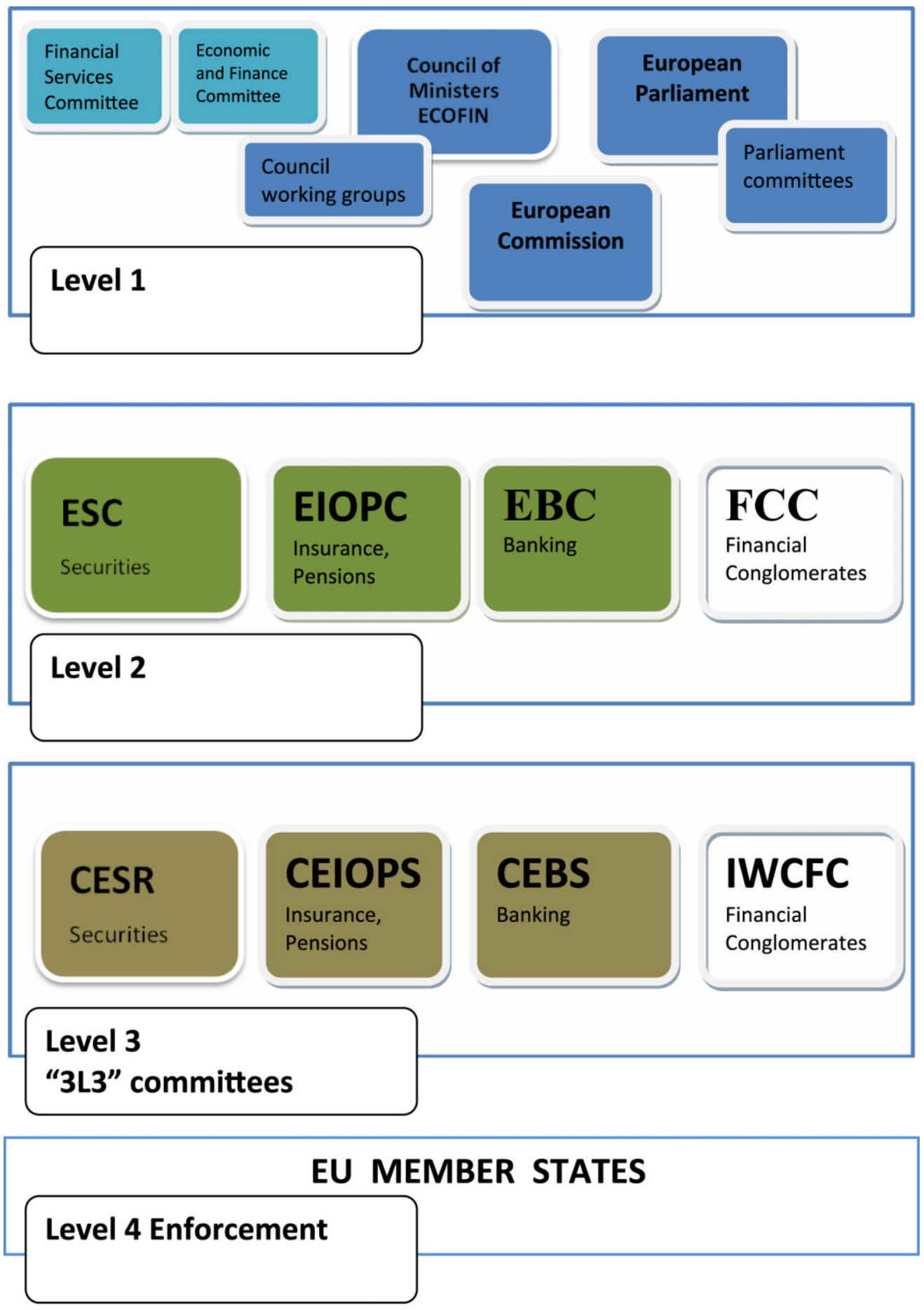
Appendix II. De Larosière Regulatory Framework

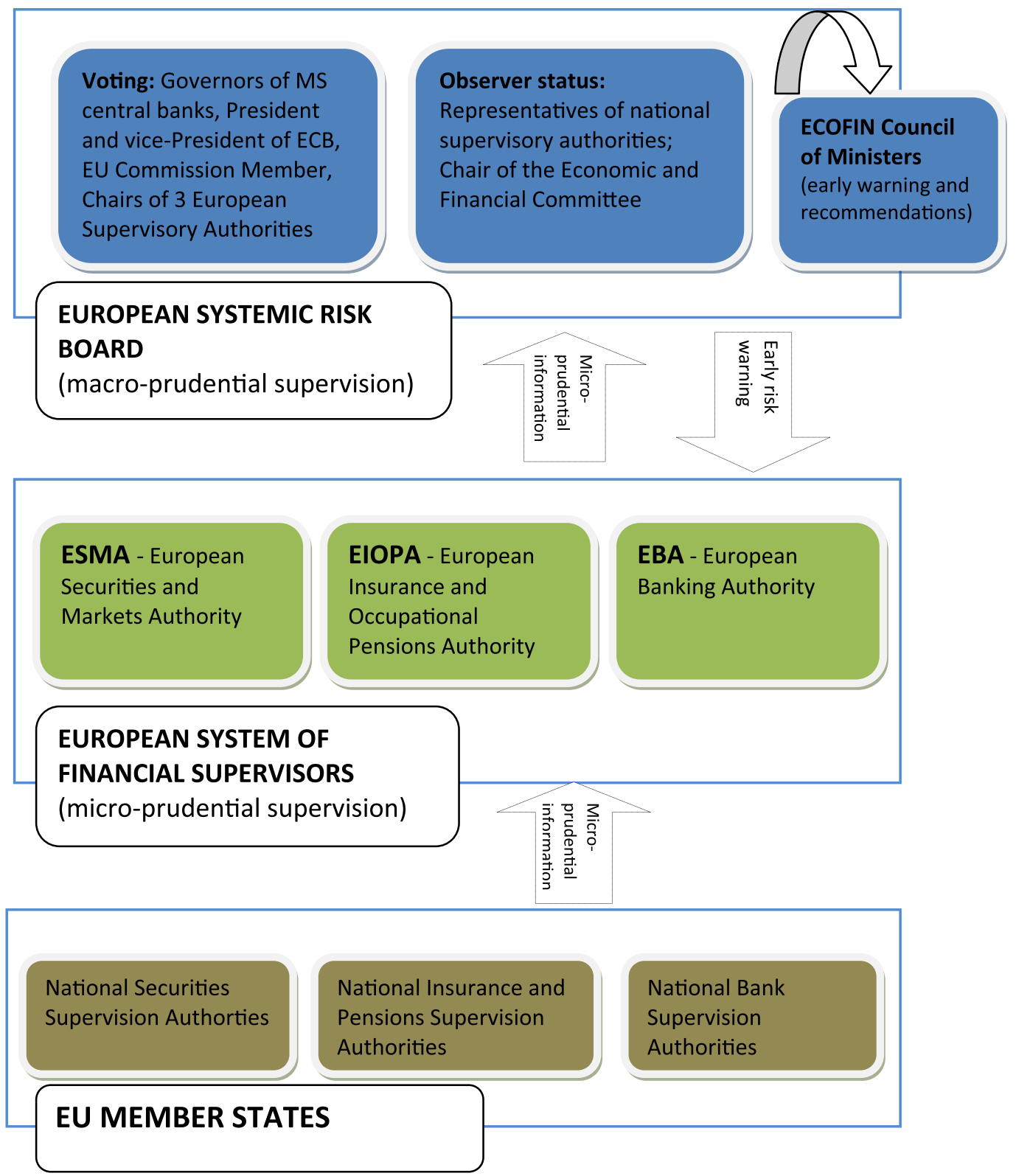




\section{Appendix III. New EU Member States' Reservations about the de Larosière Framework}

\begin{tabular}{|c|c|c|c|c|}
\hline $\begin{array}{l}\text { EU Member } \\
\text { State }\end{array}$ & $\begin{array}{l}\text { Division of } \\
\text { competences }\end{array}$ & $\begin{array}{l}\text { National } \\
\text { discretions }\end{array}$ & $\begin{array}{l}\text { Dispute } \\
\text { settlement }\end{array}$ & Score \\
\hline Bulgaria & $\begin{array}{l}\text { Day-to-day supervision } \\
\text { national. } \\
\text { Home-host supervision. }\end{array}$ & Preserve some. & $\begin{array}{l}\text { Calls for fairness in } \\
\text { mediation. }\end{array}$ & 4 \\
\hline $\begin{array}{l}\text { Czech } \\
\text { Republic }\end{array}$ & $\begin{array}{l}\text { Supervision at national } \\
\text { level. } \\
\text { Home-host supervision. }\end{array}$ & $\begin{array}{l}\text { No national } \\
\text { discretions. }\end{array}$ & $\begin{array}{l}\text { Against legally binding } \\
\text { mediation and decisions. } \\
\text { Accountability concerns. }\end{array}$ & 5 \\
\hline Estonia & $\begin{array}{l}\text { Day-to-day supervision } \\
\text { national. } \\
\text { Home-host supervision. }\end{array}$ & $\begin{array}{l}\text { Preserve some. } \\
\text { Flexibility } \\
\text { mechanisms. }\end{array}$ & $\begin{array}{l}\text { Against ECB role in } \\
\text { mediation. }\end{array}$ & 5 \\
\hline Hungary & $\begin{array}{l}\text { Day-to-day supervision } \\
\text { national. } \\
\text { Home-host supervision. }\end{array}$ & Preserve some. & & 3 \\
\hline Latvia & & & $\begin{array}{l}\text { Against legally binding } \\
\text { mediation and decisions. } \\
\text { Accountability concerns. }\end{array}$ & 2 \\
\hline Lithuania & & $\mathrm{n} / \mathrm{a}$ & & \\
\hline Poland & $\begin{array}{l}\text { Home-host supervision. } \\
\text { National decision on } \\
\text { capital requirements. }\end{array}$ & & $\begin{array}{l}\text { Against legally binding } \\
\text { mediation and decisions. } \\
\text { Accountability concerns. }\end{array}$ & 4 \\
\hline Romania & $\begin{array}{l}\text { Home-host supervision. } \\
\text { Respect subsidiarity } \\
\text { principle. }\end{array}$ & & $\begin{array}{l}\text { Against legally binding } \\
\text { mediation and decisions. }\end{array}$ & 3 \\
\hline Slovakia & $\begin{array}{l}\text { Day-to-day supervision } \\
\text { national. } \\
\text { Home-host supervision. }\end{array}$ & Preserve some. & $\begin{array}{l}\text { Against legally binding } \\
\text { mediation and decisions. } \\
\text { Accountability concerns. }\end{array}$ & 5 \\
\hline Slovenia & $\begin{array}{l}\text { Concerns whether } \\
\text { Commission has legal basis } \\
\text { to delegate powers to ESAs } \\
\text { (Meroni case). }\end{array}$ & & $\begin{array}{l}\text { Against legally binding } \\
\text { decisions. } \\
\text { Accountability concerns. }\end{array}$ & 3 \\
\hline
\end{tabular}

\section{References}

Begg, I. (2009) 'Regulation and Supervision of Financial Intermediaries in the EU: The Aftermath of the Financial Crisis'. JCMS, Vol. 47, No. 5, pp. 1107-28.

Berglöf, E. and Bolton, P. (2002) 'The Great Divide and Beyond: Financial Architecture in Transition'. Journal of Economic Perspectives, Vol. 16, No. 1, pp. 77-100.

Bini Smaghi, L. (2009) 'Going Forward: Regulation and Supervision after the Financial Turmoil'. Research Paper 2009-47 (Milan: Paolo Baffi Centre).

Bonin, J. and Wachtel, P. (1999) 'Lessons from Bank Privatization in Central Europe'. Paper presented at the World Bank and Federal Reserve Bank of Dallas Conference, Dallas, TX, 19-20 November.

Cecchetti, S., Kohler, M. and Upper, C. (2009) 'Financial Crises and Economic Activity'. Working Paper (Basel: Bank for International Settlements). 
Commission of the European Communities (2005) 'White Paper. Financial Services Policy 20052010'. Available at: «http://europa.eu/legislation_summaries/internal_market/single_market_ services/financial_services_general_framework/133225_en.htm».

Commission of the European Communities (2008) Eurobarometer 69: Public Opinion in the European Union (Brussels: Commission of the European Communities). Available at: «http:// ec.europa.eu/public_opinion/archives/eb/eb69/eb_69_first_en.pdf».

Commission of the European Communities (2009a) 'European financial supervision'. COM(2009) 252 final.

Commission of the European Communities (2009b) 'Proposal for a regulation on Community macro prudential oversight of the financial system and establishing a European Systemic Risk Board'. COM(2009) 499 final.

Commission of the European Communities (2009c) 'Proposal for a directive in respect of the powers of the European Banking Authority, the European Insurance and Occupational Pensions Authority and the European Securities and Markets Authority'. COM(2009) 576 final.

Czech Republic (2009) 'Position of the Czech National Bank on the Communication from the Commission - European Financial Supervision'. Available at: «http://circa.europa.eu/Public/ irc/markt/markt_consultations/library».

De Vries, C. (2010) 'EU Issue Voting; Asset or Liability: How European Integration Affects Parties' Electoral Fortunes'. European Union Politics, Vol. 11, No. 1, pp. 89-117.

De Vries, C. and Edwards, E. (2009) 'Taking Europe to Its Extremes: Extremist Parties and Public Euroscepticism'. Party Politics, Vol. 15, No. 1, pp. 5-28.

Epstein, R. (2008a) In Pursuit of Liberalism: International Institutions in Postcommunist Europe (Baltimore, MD: Johns Hopkins University Press).

Epstein, R. (2008b) 'The Social Context of Conditionality: Internationalizing Finance in Postcommunist Europe'. Journal of European Public Policy, Vol. 15, No. 6, pp. 880-98.

Estonia (2009) 'Estonian Response to Jacque de Larosière Report'. Available at: «http:// circa.europa.eu/Public/irc/markt/markt_consultations/library».

Estrin, S. (2009) 'Transition after the Crisis'. Development and Transition, No. 13. Available at: «http://www.developmentandtransition.net/uploads/issuesAttachments/25/

DT.13_English_FINAL.pdf».

EurActiv (2009a) 'Ministers Approve Financial Watchdogs, Giving Safeguards to UK'. EurActiv, 3 December.

EurActiv (2009b) 'The Road after de Larosière'. EurActiv, 15 September.

EurActiv (2010) 'Zapatero Pushes for EU Financial Risk Board'. EurActiv, 7 January.

European Bank for Reconstruction and Development (EBRD) (2009) 'Structural Change Indicators'. Available at: «http://www.ebrd.com/pages/research/analysis/forecasts.shtml».

European Bank for Reconstruction and Development (EBRD) (2010) 'Economic Statistics and Forecasts'. Available at: «http://www.ebrd.com/country/sector/econo/stats/index.htm».

European Central Bank (ECB) (2007) Review of the Lamfalussy Framework: Eurosystem Contribution (Frankfurt: ECB).

Financial Services Authority (FSA) (2009) The Turner Review (London: FSA). Available at: «http://www.fsa.gov.uk/pubs/other/turner_review.pdf».

Fries, S. (2005) 'Politics of Banking Reform and Development in the Post-communist Transition'. Working Paper (London: European Bank for Reconstruction and Development).

Goetz, K. (2004) 'The New Member States and the EU'. In Bulmer, S. and Lequesne, C. (eds) Member States and the European Union (Oxford: Oxford University Press).

Gourevitch, P. (1978) 'Second Image Reversed: The International Sources of Domestic Politics'. International Organization, Vol. 32, No. 4, pp. 881-912. 
Griffith-Jones, S. and Ocampo, J.A. (2009) 'The Financial Crisis and Its Impact on Developing Countries'. UNDP Working Paper (New York: United Nations Development Programme).

Hall, P. and Soskice, D. (2004) 'An Introduction to Varieties of Capitalism.' In Varieties of Capitalism: The Institutional Foundations of Comparative Advantage (Oxford: Oxford University Press).

Hampl, M. (2010) 'The EU is Making a Big Mistake on Banking Supervision'. Europe's World. Available at: «http://www.europesworld.org/NewEnglish/Home_old/Article/tabid/191/ ArticleType/ArticleView/ArticleID/21585/TheEUismakingabigmistakeonbankingsupervision. aspx».

Hodson, D. and Quaglia, L. (2009) 'European Perspectives on the Global Financial Crisis: Introduction'. JCMS, Vol. 47, No. 5, pp. 939-53.

Hooghe, L., Bakker, R., Brigevich, A., de Vries, C., Edwards, E., Marks, G., Rovny, J., Steenbergen, M. and Vachudova, M.A. (2010) 'Reliability and Validity of the 2002 and 2006 Chapel Hill Expert Surveys on Party Positioning'. European Journal of Political Research, Vol. 49, pp. 687-703.

House of Lords European Union Committee (2009) '14th Report of Session 2008-09. The Future of EU Financial Regulation and Supervision. Volume II: Evidence Ordered to be printed 9 June 2009 and published 17 June 2009'. Available at: «http://www.publications.parliament.uk/pa/ ld200809/ldselect/ldeucom/106/106i.pdf».

Hungary (2009a) 'Comments by the Ministry of Finance of Hungary on de Larosière Report and the Communication of the Commission'. Available at: «http://circa.europa.eu/Public/irc/markt/ markt_consultations/library».

Hungary (2009b) 'Comments and Views of the Central Bank of Hungary on the de Larosière Report'. Available at: «http://circa.europa.eu/Public/irc/markt/markt_consultations/library».

Johnson, J. (2008) 'The Remains of Conditionality: The Faltering Enlargement of the Euro Zone'. Journal of European Public Policy, Vol. 15, No. 6, pp. 826-41.

Lannoo, K. (2008) 'Concrete Steps towards More Integrated Financial Oversight: The EU's Policy Response to the Crisis'. CEPS Task Force Report (Brussels: CEPS).

Latvia (2009) 'Latvian Opinion on the Report from the High-level Working Group Chaired by $\mathrm{Mr}$ Jacques de Larosière'. Available at: «http://circa.europa.eu/Public/irc/markt/markt_ consultations/library».

Lindstrom, N. and Piroska, D. (2007) 'The Politics of Europeanization in Europe's Southeastern Periphery: Slovenian Banks and Breweries on Sale?' Competition and Change, Vol. 11, No. 2, pp. 117-35.

Masciandro, D., Nieto, M. and Quintyn, M. (2009) 'Financial Supervision in the EU: Is There Convergence in the National Architectures?' Journal of Financial Regulation and Compliance, Vol. 17, No. 2, pp. 86-92.

May, P. (1992) 'Policy Learning and Failure'. Journal of Public Policy, Vol. 12, No. 4, pp. 331-54. Mayes, D. (2009) 'Did Recent Experience of a Financial Crisis Help in Coping with the Current Financial Turmoil? The Case of the Nordic Countries'. JCMS, Vol. 47, No. 5, pp. 997-1015. Morow, T. (2009) 'Joint Initiatives can Rescue Eastern Europe'. Financial Times, 25 January. Österreichische Nationalbank (ÖNB) (1999) Focus on Transition 2/1999 (Vienna: Österreichische Nationalbank, Printing Office).

Parker, G. and Masters, B. (2009) 'Darling Pressed to Hold Back on EU Regulation'. Financial Times, 15 November.

Personal Interview 1 (2010) Member of old EU Member State Permanent Representation in Brussels, conducted on 29 November 2010.

Personal Interview 2 (2010) Member of old EU Member State Permanent Representation in Brussels, conducted on 7 December 2010. 
Personal Interview 3 (2010) Member of new EU Member State Permanent Representation in Brussels, conducted on 9 December 2010.

Personal Interview 4 (2011) Member of new EU Member State Permanent Representation in Brussels, conducted on 18 March 2011.

Poland (2009) 'KNF Response to European Commission Consultation on the Future of Financial Services Supervision in the EU'. Available at: «http://circa.europa.eu/Public/irc/markt/ markt_consultations/library».

Putnam, R. (1988) 'Diplomacy and Domestic Politics: The Logic of Two-Level Games'. International Organization, Vol. 42, No. 3, pp. 427-60.

Quaglia, L. (2007) 'The Politics of Financial Services Regulation and Supervision Reform in the European Union'. European Journal of Political Research, Vol. 46, No. 2, pp. 269-90.

Quaglia, L. (2010) Governing Financial Services in the European Union: Banking, Securities and Post-trading (London: Routledge).

Reinhart, C. and Rogoff, K. (2009) This Time is Different: Eight Centuries of Financial Folly (Princeton, NJ: Princeton University Press).

Romania (2009) 'Romania's Position to the European Commission's Public Consultation on Financial Supervision in the European Union'. Available at: «http://circa.europa.eu/Public/irc/ markt/markt_consultations/library».

Rose, R. (1993) Lesson Drawing in Public Policy: A Guide to Learning across Time and Space (Chatham, NJ: Chatham House).

Schoenmaker, D. and Oosterloo, S. (2008) 'Financial Supervision in Europe: A Proposal for a New Architecture'. In Jonung, L., Walkner, C. and Watson, M. (eds) Building the Financial Foundations of the Euro: Experiences and Challenges (London: Routledge).

Sissenich, B. (2006) Building States without Society: European Union Enlargement and the Transfer of EU Social Policy to Poland and Hungary (Lanham, MD: Rowman \& Littlefield).

Slovakia (2009) 'Comments by the Slovak Republic on the Report of the High-Level Working Group on Financial Supervision in the EU Chaired by Jacques de Larosière'. Available at: «http://circa.europa.eu/Public/irc/markt/markt_consultations/library».

Steenbergen, M., Edwards, E. and de Vries, C. (2007) 'Who's Cueing Whom? Mass-Elite Linkages and the Future of European Integration'. European Union Politics, Vol. 8, No. 1, pp. $13-35$.

Stone, D. (1999) 'Learning Lessons and Transferring Policy across Time, Space and Disciplines'. Politics, Vol. 19, No. 1, pp. 51-9.

Taggart, P. and Szczerbiak, A. (2002) 'The Party Politics of Euroscepticism in EU Member and Candidate States'. Working Paper 51 (Brighton: Sussex European Institute).

Tait, N. (2009) 'Big Promises Fail to Dispel Prosaic Doubts'. Financial Times, 24 September.

Tait, N. (2010) 'High Hopes for EU Financial Regulation Deal'. Financial Times, 1 September.

Vachudova, M.A. (2005) Europe Undivided: Democracy, Leverage and Integration after Communism (Oxford: Oxford University Press).

Vachudova, M.A. (2008) 'Tempered by the EU? Political Parties and Party Systems before and after Accession'. Journal of European Public Policy, Vol. 15, No. 6, pp. 861-79. 